\title{
O DIREITO, A MORAL E A RELIGIÃO
}

\author{
LAW, MORALS AND RELIGION
}

Fabiano Yuji Takayanagi*

\begin{abstract}
Resumo:
Trata-se de uma pesquisa que se inicia nos conceitos do Direito, como normas postas a fim de conduzir uma sociedade, da Moral, como normas internas psicológicas para a própria conduta do indivíduo, e da Religião, como explicação de muitos fenômenos desconhecidos ou até mesmo caminhos a serem trilhados, a fim de se chegar ao ponto que tais definições se tocam, ou até mesmo ao ponto que se unem como uma unidade.

Para isso, será feita um estudo à luz da análise dos pensadores jurídicos, filosóficos e teológicos que tentaram exaustivamente chegar a um consenso único, mas incerto.

E ainda, será examinado o Direito muçulmano para demonstrar tamanha influência da religião em suas morais, seja na família, seja nas relações comerciais, bem como na elaboração do Direito, como forma de conduta do povo islâmico.
\end{abstract}

Palavras-chave: O Direito. A Moral. A Religião. O entrelaçamento Direito-MoralReligião no mundo islâmico.

\begin{abstract}
:
This text is about a research that starts with the concepts of Law, as a posed norms to lead a society; morals, as internal and psychological norms to the self conduct of individuals; religion, as an explanation of a lot of unknown events or even ways to go ahead, to reach the point that these definitions interrelate, or even to the point that constitute an unity. For this purpose, a study was made according to legal, philosophic and theological thinkers that exhaustively tried to reach to a unique, but uncertain consensus. Furthermore, Muslim Law was analyzed to demonstrate the great influence of religion in morals, family and commercial relations, as well as in the creation of Law as a way of conduct of the Islamic people.
\end{abstract}

Keywords: Morals. Religion. The Law-Morals-Religion interrelation in Islamic World.

\section{Introdução}

Os conceitos

A Enciclopédia Larousse Cultural afirma que a maior parte dos antigos considera que a etimologia da palavra religião provém de religare, termo latino que significa ligação, seja no sentido de um vínculo de obrigação referente a certas práticas ou a certos ritos, seja no sentido de união do homem com os deuses ou com o sagrado.

\footnotetext{
Aluno do Curso de Graduação da Faculdade de Direito da Universidade de São Paulo.
} 
Assim, define-se religião em vários conceitos, quais sejam, o conjunto determinado de crenças, de dogmas que regulam a relação do homem com o sagrado; conjunto de práticas, de ritos específicos, próprios a cada uma dessas crenças; instituição social caracterizada pela existência de uma comunidade de indivíduos unidos pelo cumprimento de certos ritos regulares e pela crença na existência de uma força sobrenatural concebida ora como difusa, ora como múltipla, ora como única (Deus), que deve ser reverenciada e obedecida; toda organização ou atividade à qual se devota um sentimento de respeito ou um dever a ser cumprido; crença, devoção, piedade; modo de pensar ou de agir; respeito escrupuloso a uma regra, a um costume, a um sentimento.

A moral, por sua vez, é definida pela Enciclopédia Larousse Cultural como a ciência do bem e do mal, teoria do comportamento humano, enquanto regido por princípios éticos (varia de cultura para cultura e se modifica com o tempo no âmbito de uma mesma sociedade), ética; corpo de preceitos e regras que visa dirigir as ações do homem, segundo a justiça e a eqüidade natural; os princípios da honestidade e do pudor, moralidade.

O Direito, por derradeiro, define a Enciclopédia Larousse Cultural como sendo um complexo de leis ou normas que regem as relações entre os homens; ciência ou disciplina que estuda essas normas; faculdade de praticar um ato, de possuir, usar exigir ou dispor de alguma coisa.

Assim sendo, a partir desses conceitos, discutiremos por meio de grandes autores do Direito e da Filosofia que explicitam suas teses e elaboram teorias que separam ou aproximam um conceito de outro.

1. A Moral

De acordo com Maria Lúcia de Arruda Aranha e Maria Helena Pires Martins, ${ }^{1}$ temos que no mundo cultural, o sistema de significados já está estabelecido por outros, logo conforme atendemos ou transgredimos os padrões, os comportamentos são avaliados como sendo bons ou maus.

As atitudes das pessoas estão sujeitas às sanções, ou seja, elogios ou reprimendas, recompensas ou punições.

As filósofas afirmam que, em sentido amplo, a moral é o conjunto de regras de conduta admitidas em determinada época ou por um grupo de homens. Dessa forma, define-se o homem moral como aquele que age bem ou mal, na medida em que acata ou transgride as regras do grupo.

\footnotetext{
ARANHA, Maria Lucia de Arruda; MARTINS, Maria Helena Pires Martins. Filosofando: introdução à filosofia. 2. ed. São Paulo: Editora Moderna, 1993.
} 
É de grande relevância a existência do mundo moral, pois é quase impossível imaginar um povo sem qualquer conjunto de regras. Aranha e Martins citam Lévi-Strauss, antropólogo francês, afirmando que a passagem do reino animal ao reino humano, portanto, da passagem da natureza à cultura, ocorreu por meio da instauração da lei, pela proibição do incesto. Assim, foi-se possível o estabelecimento das relações de parentesco e de aliança sobre as quais é constituído o mundo humano, que é simbólico.

Ambas estudiosas da Filosofia afirmam que o comportamento moral varia de acordo com tempo e o lugar, conforme as exigências das condições nas quais os homens se organizam ao estabelecerem as formas efetivas e praticas de trabalho. Cada vez que as relações de produção são alteradas, sobrevêm modificações nas exigências das normas de comportamento coletivo.

É exemplo o ocorrido na Idade Média, período caracterizado pelo regime feudal na relação de suserania e vassalagem, bem como a existência dos servos. O trabalho era garantido pelos servos possibilitando aos nobres a vida no ócio e na guerra. A moral cavalheiresca reside no pressuposto da superioridade da classe dos nobres, exaltando a lealdade e a fidelidade, pilares do sistema de suserania e vassalagem, e a coragem do guerreiro. Em contrapartida, o trabalho era desvalorizado e remetido aos servos. Porém, com o decorrer do tempo, esse conceito é modificado com o aparecimento da burguesia transformando os valores, os quais o trabalho passa a ser idealizado e buscado. Dessa forma, foi possível entender que o tempo e as relações interpessoais modificaram o valor moral a ser seguido.

Entretanto, a moral não se reduz aos valores herdados da tradição. Por exemplo, as sociedades primitivas, as quais tiveram sua moral modificada na medida em que os grupos tribais abandonaram a consciência mítica e desenvolveram o questionamento racional.

Nesse sentido, na proporção que o grau de consciência e de liberdade ampliam, um elemento contraditório passa a ser instigado no homem, a moral, ao mesmo tempo que é o conjunto de regras que determinantes do comportamento dos indivíduos do grupo, é também a livre e consciente aceitação das normas.

Por conseguinte, o ato só é propriamente moral se passar pelo crivo da aceitação pessoal da norma. A exterioridade da moral contrapõe-se à necessidade da interioridade, da adesão mais íntima, de acordo com Maria Lúcia de Arruda Aranha e Maria Helena Pires Martins.

Assim, a vida moral se funda numa ambigüidade fundamental, justamente a que determina seu caráter histórico. Toda moral está situada no tempo e reflete o mundo em que nossa liberdade esteja situada, logo as normas adequadas em determinado momento, tornam-se caducas e obsoletas em outro momento e devem ser alteradas. Dessa forma, as contradições entre o velho e novo são vividas, quando as relações estabelecidas entre os 
homens, ao produzirem sua existência por meio do trabalho, exigem um novo código de conduta.

Analisando os fatos morais, percebemos a existência de dois pólos contraditórios; de uma extremidade, temos o caráter social da moral e, de outra, a intimidade do sujeito. Por essa razão, segundo Aranha e Martins, é preciso considerar os dois extremos contraditórios do pessoal e do social numa relação dialética, numa relação que estabeleça o tempo todo a implicação recíproca entre o determinismo e liberdade, entre adaptação e desadaptação à norma, aceitação ou recusa da interdição.

Quanto ao aspecto social da moral, ele é considerado sob dois pontos de vista. O primeiro seria apenas a herança dos valores do grupo, mas depois de passar pelo crivo da dimensão pessoal, o social readquire a perspectiva humana e madura que destaca a ênfase na intersubjetividade essencial da moral. Assim, quando criamos valores, não o fazemos para nós mesmos, mas enquanto seres sociais que se relacionam com os outros.

Em relação aos atos morais executados pelos seres humanos, podemos dividi-los em dois sentidos: o normativo e o fatual. Este são os atos humanos enquanto se realizam efetivamente e aquele são as normas ou regras de ação e os imperativos que enunciam o dever ser. Ambos são distintos, porém inseparáveis em que a norma tem sentido somente se orientada para a prática, e o ato fatual só adquire contorno moral quando se refere à norma.

$\mathrm{O}$ ato efetivo será moral ou imoral, conforme esteja de acordo ou-não com a norma estabelecida. Já se considera amoral o ato realizado à margem de qualquer consideração a respeito das normas. Trata-se da redução ao fatual, negando-se o normativo.

As filósofas supracitadas discutem quanto ao dever e a liberdade, afirmando que o comportamento moral é consciente, livre e responsável. Além disso, é obrigatório e cria um dever.

A consciência moral, como juiz interno, avalia a situação, consulta as normas estabelecidas, as interioriza como suas ou-não, toma decisões e julga seus próprios atos. O compromisso derivado disso é a obediência à decisão. E para sabermos se realmente somos livres, deve-se ter a possibilidade sempre aberta da transgressão.

Assim sendo, temos que a moral nada mais é que uma conduta a ser seguida, porém conduta esta que está a critério da pessoa a praticá-la, pois há a liberdade de infringir uma atitude moral comum de um determinado povo. A sanção, por sua vez, pode ser psicológica, ou até mesmo a repulsa do infrator seguida de morte, como ocorre em certos 
países do Oriente, por exemplo, no Afeganistão onde caso ocorra o adultério, o adúltero será lapidado, isto é, apedrejado até a morte. ${ }^{2}$

2. A religião

A religião, conforme a definição explicitada pela Enciclopédia Larousse Cultural, de maneira geral, é um modo de pensar e agir. Ela é um meio de muitos povos se apoiarem para poderem seguir seus destinos, uma explicação para diversos fenômenos naturais ou-não em que a ciência moderna se mostra incapaz de evidenciar de maneira racional.

Nessa acepção, temos conjuntamente o mito, ${ }^{3}$ que constitui, nas palavras de José Luiz Fiorin, uma explicação do homem para aquilo que é inexplicável, é uma súmula do conhecimento de cada cultura a respeito das grandes questões com que o ser humano sempre se debateu.

Assim, há no mito uma explicação das origens do homem, do mundo, da linguagem; a compreensão do sentido da dor, da morte, da vida, da condição humana. E enquanto a ciência não puder explanar a origem das coisas e o seu sentido, atua o pensamento mítico.

Em Gênesis, citada por Fiorin, temos a criação do céu, da terra, do mundo por um ente divino e superior, Deus. Explica-se o nascimento do primo homem e de sua costela, a mulher, eis que surgem Adão e Eva. Todos os seres vivos seriam feitos de barro da terra, seus corpos, e do sopro de Deus, suas almas.

Depois dessas criações divinas, o homem é colocado no paraíso terreal, onde não precisa trabalhar, não sente dores, não morre, não sente frio, convive em harmonia com a natureza. Porém, após o homem provar o fruto proibido, transita da natureza para a cultura e a marca é o aparecimento da vergonha, estado específico de alma do ser humano. Quando em estado natural, Adão e Eva andavam nus e pós-fruto proibido, cobriram-se envergonhados fazendo para si uma veste.

A partir dessa transgressão da norma celestial, a mulher foi condenada a dar à luz em meio às dores e a estar sujeita ao homem. O homem, por sua vez, ficou submetido ao tempo, à morte; a natureza passou a ser lhe hostil e foi obrigado a trabalhar para subsistência.

A partir da Gênese, muitas explicações da natureza e da vida humana passaram a ser entendidas e seguidas. Foi a religião-mítica fazendo parte das sociedades para assim poderem progredir no tempo.

\footnotetext{
2 Folha de S. Paulo, São Paulo, domingo, 12 de agosto de 2001.

3 FIORIN, José Luiz. As astúcias da enunciação. 2. ed. São Paulo: Editora Ática, 2002.
} 
Nesse mesmo plano, podemos mencionar o Alcorão, Livro Sagrado dos islâmicos, que segundo o emérito jornalista e bacharel em Direito pela USP, Antonio Augusto Machado de Campos Neto em A Châr'ia Muçulmana, ${ }^{4}$ em que foi feita uma edição completa do livro no califado de Abu Bakr e nele constam não apenas mando de condutas, como também há a incorporação de toda uma conjectura histórica da civilização muçulmana e revelações de Allah ao seu Profeta Mohammad.

O Livro Sagrado é uma obra doutrinária com preceitos ainda respeitados no mundo árabe e revela uma distinção entre o Paraíso e o Inferno em que o primeiro é belo e alegre e o segundo, triste e local de chamas. O Paraíso é o destino daqueles que seguirem o Islã e vierem a morrer combatendo os infiéis.

No Alcorão, explica Machado de Campos Neto, não se exige a construção de templos grandiosos para seus seguidores, bastaria um tapete para tornar-se uma mesquita e nele os fiéis orarem voltados à Meca, de acordo com os ensinamentos de Mohammad.

A mulher deve ter uma conduta submissa, exige-se que mantenha os olhos abaixados evitando que não sejam vistos seus ornamentos, com exceção dos pais e marido. Há contrariedade às bebidas, no Livro Sagrado, e sua transgressão leva à punições severas.

Machado de Campos Neto cita Hayek dizendo que o Alcorão é dirigido a todos, sem qualquer distinção de raça, cor, região ou tempo e o propósito do Livro Sagrado seria guiar os seres humanos na direção de todas as sendas da vida: espiritual, material, individual e coletiva.

Em tempos passados, no século XVIII, François Marie Arouet, o Voltaire, pensador de conceito elevado em sua época, explicita sobre religião em seu livro, ${ }^{5}$ citando o bispo de Gloester, Warburton, que uma religião, uma sociedade que não estão fundadas sobre a crença numa outra vida devem ser mantidas por uma providência extraordinária. O judaísmo não está fundado sobre uma crença numa outra vida; portanto o judaísmo foi mantido por uma providência extraordinária.

Voltaire acrescenta opinião oposta de muitos teólogos da época em que toda a religião deveria estar lastreada no dogma da imortalidade da alma, nas penas e recompensas eternas, caso não estivessem embasada nesses princípios, a religião seria falsa. Por essa razão, condenava-se o judaísmo, justamente por não reconhecer os referidos dogmas, logo estaria longe de ser sustentado pela Providência.

O filósofo francês coloca em outra questão a necessidade dos burgos, devido suas fraquezas e necessidade de um forte protetor, em adorar cada um, um determinado

\footnotetext{
4 CAMPOS NETO, Antonio Augusto Machado de. A Châr'ia Muçulmana. Revista da Faculdade de Direito da Universidade de São Paulo, São Paulo, v.101, p. 33-70, jan./dez. 2006.

VOLTAIRE. Dicionário Filosófico. Ed. Martin Claret. São Paulo, 2004.
} 
ente superior. E foi assim que se encontrou toda a América dividida em uma multidão de pequenas populações, tendo, todas, seu deus protetor. Os próprios mexicanos, os peruanos, que eram grandes nações, tinham apenas um deus: uns adoravam Maco Capaque, outros o deus da guerra. Os mexicanos chamavam o seu deus guerreiro de Vitzputzli, assim como os hebreus haviam chamado seu senhor de Sabaoth.

Voltaire, em uma terceira questão do tema religião de seu livro, coloca que o platonismo auxiliou na compreensão dos dogmas, que em certo tempo o culto de um Deus supremo estava universalmente estabelecido na opinião de todos os sábios, na Ásia, na Europa e na África, que a religião cristã nasceu e se desenvolveu.

O filósofo alega que o Logos para Platão era sinônimo de sapiência, a razão do Ser Supremo, tornou-se em nossos tempos o Verbo e uma segunda pessoa de Deus. Uma metafísica profunda e acima da inteligência humana foi um santuário inacessível no qual a religião se desenvolveu.

Pois bem, ante todas as explanações sobre a religião, é possível se inferir que o tema traz uma ligação do homem com o sagrado e através dessa conexão, buscaramse explicações para o mundo, para as dores e caminhos a serem trilhados. Além disso, a crença da existência de uma ou mais forças naturais superiores passou, em muitos países do Oriente, por exemplo, a ser base de conduta de todo o povo.

Nesse sentido, a fé pregada pode ser um meio de ordenar um país, uma população e delimitar os atos humanos mediante as sanções divinas, seja na vida terrena, seja na vida extraterrena, é o que ocorre, como visto, no universo islâmico. Embora no mundo ocidental tente-se afastar a religião em seus ordenamentos jurídicos, é fato que as doutrinas religiosas, apesar de muitos países se declararem laicos, influenciam a moral e, por conseguinte, o Direito aplicado.

\section{O Direito}

O Direito para o ilustre jurista Miguel Reale em seu livro ${ }^{6}$ que define o conceito como sendo lei e ordem, ou seja, um conjunto de regras obrigatórias que garante a convivência social graças ao estabelecimento de limites à ação de cada um de seus membros.

Acrescenta Reale que o Direito corresponde à exigência essencial e indeclinável de uma convivência, afinal, nenhuma sociedade poderia subsistir sem um mínimo de ordem, de direção de solidariedade.

É passível de citação o brocardo latino ubi jus, ibi societas, isto é, não se pode conceber qualquer atividade social desprovida de forma e garantia jurídicas, nem

\footnotetext{
6 REALE, Miguel. Lições preliminares de direito. 27. ed. São Paulo: Editora Saraiva, 2002.
} 
qualquer regra jurídica que não se refira à sociedade. Ainda nesse sentido, o ínclito jurista diz que o Direito é um fato ou fenômeno social e não existe senão na sociedade e não pode ser concebido fora dela.

O emérito jurista Tércio Sampaio Ferraz Júnior, ${ }^{7}$ por sua vez, define o Direito citando Arnold que seria correspondente a uma certa atitude, uma forma de pensar, uma maneira de referir-se às instituições humanas em termos idéias. Trata-se de uma exigência do senso comum, profundamente arraigada, no sentido de que aquelas instituições de governo dos homens e de suas relações simbolizem um sonho, uma projeção real, dentro de cujos limites funcionam certos princípios, com independência dos indivíduos.

Ferraz Jr., afirma ainda que o Direito possui simultaneamente as filosofias da obediência e da revolta, servindo para expressar e produzir a aceitação do status quo, da situação existente, mas aparecendo também como sustentação moral da indignação e da rebelião.

Serve, portanto, o Direito para proteção do poder arbitrário, exercido nos limítrofes de toda a regulamentação, e oferece a todos oportunidades iguais, amparando os desfavorecidos.

Hans Kelsen ${ }^{8}$ define o Direito, a partir de duas formas: a primeira entende o conceito como uma ordem de conduta humana e a segunda, como uma ordem coativa.

O jusfilósofo afirma ser uma ordem, um sistema de normas cuja unidade é constituída pelo fato de todas elas terem o mesmo fundamento de validade. E o fundamento de validade de uma ordem normativa é uma norma fundamental da qual se retira a validade de todas as normas pertencentes a essa ordem. Assim, uma norma singular é norma jurídica, desde que seja válida e fundada na norma fundamental dessa ordem. Declara Kelsen que as normas de uma ordem jurídica regulam a conduta humana, porém isso só se aplica às ordens sociais de povos civilizados e não nas sociedades primitivas.

Ademais, Hans Kelsen explicita que, enquanto uma ordem jurídica é uma ordem social, ela somente regula, de uma maneira positiva, a conduta de um individuo enquanto esta se refere a outro individuo.

Outra forma de se abstrair o Direito é considerá-lo como uma ordem coativa, ou seja, reage contra situações consideradas indesejáveis, por serem socialmente perniciosas, Kelsen aponta principalmente contra as condutas humanas indesejáveis, com um ato de coação, um mal aplicado ao destinatário mesmo contra a sua vontade utilizandose até mesmo a força física.

Nesse sentido, as ordens sociais chamadas por Direito, são ordens coativas da conduta humana unindo ambas as definições em uma só.

\footnotetext{
7 FERRAZ JR., Tércio Sampaio. Introdução ao estudo do direito. 4. ed. São Paulo: Editora Atlas, 2003.

8 KELSEN, Hans. Teoria pura do direito. 6. ed. 5. tir. São Paulo: Editora Martins Fontes, 2003.
} 


\subsection{O Direito Natural e o Direito Positivo}

Antes de se passar ao próximo capítulo, cabe ressaltar duas definições contrapostas nas quais o Direito se divide.

A primeira delas é a do Direito Natural que no pensamento clássico, segundo Norberto Bobbio, ${ }^{9}$ era aquele está em toda a parte (pantachô̂) e tem sempre a mesma eficácia. Em esfera diametralmente oposta, o Direito Positivo tem eficácia apenas nas comunidades políticas singulares em que é posto, portanto, o primeiro é universal e o segundo, particular.

O jusfilósofo afirma que ao contrário do Direito Positivo, o Direito Natural no pensamento clássico, prescreve ações cujo valor não depende do juízo que sobre elas tenha o sujeito, mas existe independentemente do fato de parecerem boas a alguns ou más a outros. O Direito Positivo, por sua vez, é aquele que estabelece ações que podem ser cumpridas indiferentemente de um modo ou de outro, porém, uma vez regulado pela lei, deve ser desempenhado no modo prescrito na lei.

Bobbio também separa essa distinção em época romana que o jus civile, referente às estatuições do populus, corresponderia ao conceito de Direito Positivo, limitado a um determinado povo e posto por ele, por uma entidade social criada pelos homens; e o jus gentium, relativo à natureza, aquele que não teria limites, posto pela naturalis ratio, o Direito Natural.

Afima Norberto Bobbio, citando Paulo apresentado no Digesto, que o Direito Natural é universal e imutável, enquanto o Direito Civil, positivo, seria particular no tempo e no espaço. Ainda, o primeiro, estabelece o que é bom, bonum et aequum, e funda-se hum juízo correspondente ao critério moral, enquanto o segundo, estabelece o que lhe é útil e baseia-se num critério econômico ou utilitário.

No pensamento medieval, segundo o jusfilósofo em referência, o Direito Positivo tinha a característica de ser posto pelos homens, em contrapartida do Direito Natural que era posto por algo, ou alguém além da humanidade, como a natureza, ou até mesmo Deus.

Entretanto, para São Tomás de Aquino, não considera a lex humana como positiva, pois a única positiva é a lex divina. Define a lex humana como derivada da lei natural por obra do legislador que põe e a faz valer, mas tal derivação pode ocorrer por dois modos: per conclusionem ou per determinationem. O primeiro é quando a lei positiva deriva daquela natural segundo um processo lógico, por meio de uma conclusão de um silogismo; e o segundo, quando a lei natural é muito geral e genérica, correspondendo ao Direito Positivo determinar o modo concreto segundo o qual essa lei deva ser aplicada.

9 BOBBIO, Norberto. O positivismo juridico. São Paulo: Editora Ícone, 1995. 
Quanto ao tempo dos pensadores dos jusnaturalistas dos séculos XVII e XVIII, segundo Norberto Bobbio, o Direito Natural seria um ditame da justa razão destinado a mostrar que um ato seria moralmente torpe ou moralmente necessário segundo seja ou-não conforme à própria natureza racional do homem, e a mostrar que tal ato seria, em conseqüência disto vetado ou comandado por Deus, enquanto Autor da natureza.

Já quanto ao Direito Positivo, temos que o Direito Civil seria aquele derivado do poder civil, e designa por poder civil aquele que seria da competência do Estado por Estado a associação perpétua de homens livres, reunidos em conjunto com o fito de gozar os próprios direitos e buscar a utilidade comum.

Bobbio, por fim, evidencia o limite entre Direito Natural e Direito Positivo como sendo a esfera do Direito Natural limitada àquilo que se demonstra a priori, a esfera do Direito Positivo, por sua vez, começa onde a decisão sobre se uma coisa constitui, ounão, direito depende da vontade de um legislador.

Assim sendo, após a exposição sobre o conceito de Direito por meio de grandes juristas, além de sua divisão em tempos do Direito Natural e do Direito Positivo, partiremos ao próximo capítulo que trará o entrelaçamento dos conceitos abordados nesta pesquisa.

\section{O entrelaçamento dos conceitos de Moral, Religião e Direito}

Neste capítulo será apresentada a evolução da distinção do Direito e da Moral e as formas nas quais o Direito pode ser influenciado pela Moral como é o caso da existência de princípios de artigos no Código Civil brasileiro que corroboram tal assertiva, bem como pela Religião e a Moral, pois em certos povos, como o muçulmano, a religião exerce grande preponderância sobre a moral que, por sua vez, define o Direito na região. É o que será demonstrado por meio da explicitação do Direito muçulmano.

\subsection{O Direito e a Moral na Grécia e em Roma ${ }^{10}$}

Afirma Miguel Reale que não fora possível de forma deliberada critérios capazes de, no tempo da Grécia, distinguir o jurídico do não-jurídico.

Na Hélade foi possível encontrar, entre os pré-socráticos uma distinção entre o justo por natureza e o justo por convenção, isto é, entre a lei natural e a lei positiva. Platão, por sua vez, explicita que os sofistas buscaram de diversas formas a compreensão da lei e da justiça, vez que as concebiam como predomínio da força, ou como resultado

${ }^{10}$ REALE, Miguel. Filosofia do Direito. 17. ed. São Paulo: Editora Saraiva, 1996. 
de um acordo, ou até mesmo como tendências naturais contra os abusos da legalidade positiva.

Chegou-se, com o tempo, à explicação contratualista do Direito que no mundo helênico foi interpretado pelos filósofos epicuristas. O Direito foi definido como uma convenção feita entre homens exaustos de agressões mútuas, de um Estado selvagem, com perigos e insegurança a todos.

Entretanto, há autores, segundo Miguel Reale, que sustentam não haver o Direito como uma convenção e, sim, como resultado de um processo inexorável de força, de poder e arbítrio.

Aristóteles, de seu modo, reconheceu existir um justo por lei e o justo por natureza em que este último haveria em toda parte na mesma intensidade, pelo fato de nãodepender de opiniões e decretos dos homens. A lei seria a inteligência menos a paixão, isto é, depurada de todas as influências capazes de lançar um homem contra outro.

Nos ensinamentos do estagirita buscou-se igualmente a apreciação do problema da justiça como bilateralidade, como "bem de outrem", uma "espécie de proporção" de homem para homem, de modo que "não há justiça de um homem para consigo mesmo".

Assim, não buscava Aristóteles descobrir um critério que distinguisse a Moral do Direito justamente devido às circunstancias históricas e culturais nas quais se desenvolveu o grande mestre.

O mundo grego era aquele no qual a Política tinha grande relevância e o que se buscava nessa época era a igualdade de todos na participação do poder, da coisa pública isonômica. Aristóteles via a política como a maior de todas as ciências, pois seria no Estado que o homem poderia atualizar suas faculdades naturais e, uma vez realizandose, alcançaria plenamente o seu bem.

Na obra do estagirita, a Teoria Geral do Estado era entendida como complexo unitário no qual o Direito não se destacava. O ínclito Miguel Reale lembra Filomusi Guelfi dizendo que, na Grécia, não existia uma palavra própria para mencionar o Direito, pois o conceito ainda se fundia no conceito universal de justo. É reconhecido que, no mundo grego, o Direito permaneceu numa dependência da Retórica e da Moral.

No mundo romano, havia uma ciência do Direito autônomo. O Direito não era apenas cultivado por moralistas, filósofos ou sacerdotes. Surgia a figura do jurisconsulto que passou a ser especialista profissional cultivando a justiça em seu sentido prático, como voluntas, e não como um dos aspectos teóricos da sabedoria.

Nas obras de Cícero, foi possível se descobrir apologias da lex como expressão da lex naturalis, sempre igual por toda a parte, que determina o que deve ser feito e o que deve ser evitado. 
Para os mestres do Direito Natural clássico, esse não é senão a Moral mesma enquanto serve de pressuposto ao Direito, expressando, por conseguinte, determinados princípios gerais de conduta, como exigências imediatas e necessárias da racionalidade humana.

Concepção diferente do Direito Natural do Renascimento que passa a ser um código da razão, capaz de conter a priori soluções adequadas para todos os problemas jurídicos emergentes da experiência concreta.

Assim, em Roma, temos uma concepção de Direito Natural como o conjunto dos princípios primordiais do agir, que refletem, de maneira imediata e necessária, as obrigações do homem e, como tais, imanentes do jus gentium, afirma Miguel Reale.

Em fragmentos de Paulo "Non omne quod licet honestum est" (D., 50, $17,144)$, temos a noção de que os romanos não confundem o lícito moral com o lícito jurídico.

Outro texto do Digesto seria o "jus est ars boni et aequi" (D., I, 1, 1) em que se diz "a arte do bom e do equitativo" que se confunde entre o Direito e a Moral.

Embora tenhamos textos do Digesto da época romana, há muitas interpretações que deixam indefinidamente dúvidas quanto a Moral e o Direito, em Roma, e suas definições e distinções.

Dessa forma, diz Reale, os romanos deixaram um monumento jurídico à espera de uma interpretação filosófica, mas constituíram o seu Direito, segundo uma filosofia implícita, resultante de sua atitude perante o universo e a vida, subordinando todos os problemas humanos às exigências e aos interesses essenciais de uma comunidade política, moral e juridicamente unitária.

\subsection{O Direito e a Moral na Idade Média ${ }^{11}$}

Foi com o advento do Cristianismo que se passou a distinguir definitivamente a Política e Religião, portanto, a atuação do Estado e ação do homem que não é somente um cidadão, mas também um homem por si só.

Graças a essa distinção entre Política e Religião que foi possível traçar fronteiras entre a Moral e o Direito. Isso não foi feito por juristas ou moralistas puros, mas por teólogos, homens voltados à compreensão de Deus e de suas relações com o homem e com o mundo.

O pensamento medieval teve como grandes personalidades de sua sustentação filosófica e teológica Santo Agostinho e São Tomás de Aquino.

11 REALE, Miguel. Filosofia do Direito. 17. ed. São Paulo: Editora Saraiva, 1996. 
Para São Tomás de Aquino, lei e ordem seriam dois conceitos que se completam e se exigem. Para o primeiro, define-se como uma ordenação da razão no sentido do bem comum, promulgada por quem dirige a comunidade. Diz-se ter um valor universal, pois não-só se aplica ao mundo humano como também se refere à ordem cósmica.

O elemento mais alto para a Filosofia tomista jurídico-moral, segundo Miguel Reale, é a lex aeterna, expressão da razão divina, é a mais alta forma de sua "participação" aos homens, porque dada por Deus, como no caso das Sagradas Escrituras.

A lex naturalis, por sua vez, é uma derivação da lex aeterna, através da força da razão, que pode conhecer aquela integralmente. Assim, a lei natural estatui aquilo que o homem deve fazer ou deixar de fazer, segundo o principio de ordem prática fundamental de toda concepção tomista, de que o bem deve ser feito e o mal evitado.

Portanto, o Direito Natural, para São Tomas de Aquino, é, em alguns mandamentos fundamentais de conduta, derivados de maneira imediata da razão, por participação da lex aeterna.

Ainda assim, temos uma derivação da própria lei natural, a lex humana que representa uma determinação ou especificação da lei natural em cada caso concreto por obra do legislador, segundos motivos de oportunidade e de conveniência.

Dessa forma, temos o escalonamento da lex aeterna à lex humana, tendo como meio a lex naturalis. Nesse sentido, fica impossível distinguir o mundo moral do mundo jurídico, pois tudo é posto como uma unidade. Seria uma concepção teocêntrica do Direito, porque fundada numa concepção do universo e da vida, logo a Moral e o Direito se integram em concepção unitária.

Ante o exposto, não fora a Idade Média que houve a distinção definitiva da Moral com o Direito diante desse momento em que houve grande influência do pensamento tomista no qual as leis eram únicas e impossibilitavam tal separação.

\subsection{O Direito e a Moral na Época Moderna ${ }^{12}$}

Foi no Renascimento que os elementos formadores da Ciência passaram a ser primordiais. Buscava-se indagar a origem dos fenômenos sem a ligação extrema teológica, pois o homem fora inserto no centro do universo.

Nesse momento surge a Escola do Direito Natural ou do Jusnaturalismo em que se tem a autoconsciência do individuo que vai resultar a lei. E ainda nesse tempo, surgem as idéias contratualistas, em contraposição do indivíduo em estado de natureza sem leis, sem normas. O Direito, por sua vez, passa a ser mais elaborado na época moderna.

12 REALE, Miguel. Filosofia do Direito. 17. ed. São Paulo: Editora Saraiva, 1996. 
Começa-se a se desenvolver o contratualismo total envolvendo a origem da sociedade e do Estado; e um contratualismo parcial tratando somente da origem do Estado. Foi aí que se passou a distinguir o Direito, fundado no contrato social, da Moral, anterior ao contrato positivo e condição primordial.

O contratualismo, segundo Miguel Reale, não seria uma doutrina, mas um movimento que abrange várias teorias muitas vezes conflitantes. Temos efeitos diferentes do contrato, quais sejam, os já ditos total ou parcial.

Cabe ressaltar que no contratualismo parcial, tivemos a diferenciação do Direito e da Moral por Grócio, pois afirmava o filósofo que o Direito Natural, expressão da moral, não possuía fundamentos contratuais, já o Direito Positivo, sim, porque era a expressão do contrato. Dessa forma, a Moral era natural, enquanto o Direito, convencional.

Além de Grócio, existiu Hobbes que defendia, no campo quanto à natureza do homem no ato de contratar, um contratualismo pessimista em que a lei é a justiça e o Rei expressão do justo. Havia a apologia de um Estado forte e absoluto, o Direito e a justiça, por sua vez, surgiam após o contrato.

Nesse mesmo pensamento, mas de maneira oposta, tivemos o contratualismo otimista defendido por Rousseau, que idealizava um homem natural corrompido por um falso contrato social. Era necessário o governo do povo, todo poder emanaria do povo, em detrimento do Estado, que estaria submetido a ele.

Em meio a essas teorias, tivemos uma intermediária na qual John Locke afirmava a possibilidade de contratar, era a vontade do homem em primeiro lugar, pois este estaria em seu estado natural, e por nascer livre e possuir um direito anterior ao contrato, o direito de liberdade, tinha a faculdade para pactuar.

Na doutrina de Kant, temos a idéia de que o homem é um ser e desde o seu nascimento, possui um direito inato, o de liberdade. Para o filósofo, ser homem é ser livre, logo existindo no homem o poder de acordar o seu arbítrio com os demais.

É através dessa doutrina, por exemplo, que se torna possível a experiência jurídica, pois a partir dela obtemos a definição do Direito como o conjunto das condições mediante as quais o arbitrio de cada um se harmoniza com os demais, segundo uma lei geral de liberdade.

Assim sendo, a partir da separação da ordem política por meio das teorias contratualistas e a busca pela descoberta por meio da arte da Ciência, o Direito passou a fazer parte dos pensamentos dos filósofos de maneira distinta da moral, em momentos diversos, possibilitando iniciar a real distinção de dois grandes conceitos até então buscados, o do Direito e a da Moral. 


\subsection{O conceito de Direito e Moral para os jusfilósofos}

Gustav Radbruch, ${ }^{13}$ em sua distinção de Direito e Moral afirma ser aquele caracterizado pela exterioridade, ou seja, o que regula a conduta exterior do homem, já esta caracterizada pela interioridade, portanto, determina a conduta interior.

O filósofo alemão declara essa ser a melhor definição da concepção de Direito como um complexo de preceitos reguladores da vida dos homens em comum, pois só há vida em comum quando o indivíduo entra na sua atividade em relação com outros indivíduos.

Alega, ainda, como sendo relevante a atitude interior que pode ser juridicamente importante, pois há casos os quais a atitude interior é decisiva no tratamento jurídico a dar a determinadas condutas exteriores. Além disso, é possível encontrar atitudes interiores que por si só já produzem determinados efeitos jurídicos, por exemplo, em seu caso no perigo moral de um menor, quando ele mesmo determina a necessidade de intervenção e a proteção do Estado.

Por conseguinte, diz Radbruch, devemos reconhecer que tanto a conduta exterior é suscetível de ser objeto de valorações morais, como a interior de ser objeto de valorações jurídicas. Nesse sentido, a conduta exterior só interessa à moral na medida em que exprime uma conduta interior; a conduta interior, por sua vez, só interessa ao Direito na medida em que anuncia ou deixa esperar uma conduta exterior.

Assim, podemos ter a vida sendo regulada por um meio externo e associada por uma atitude interna, ou mesmo uma atitude interna que por si só já produz efeitos externos jurídicos. E o Direito não pretende somente julgar a conduta humana, também influenciada pela moral, mas também determiná-la em harmonia com os seus preceitos e impedir toda conduta contrária a eles.

Os professores Eduardo Carlos Bianca Bittar e Guilherme Assis de Almeida, ${ }^{14}$ em suas opiniões, afirmam que o Direito pode caminhar em consonância com os ditames morais de uma sociedade, mas também pode andar em dissonância com a moral.

Temos que no primeiro caso, um Direito moral, e no segundo caso, um Direito imoral. Entretanto, pode ser um Direito imoral tão válido quanto o Direito moral, os professores afirmam que o último é o mais quisto, pois em sua base de formação se encontra o consentimento popular, ou seja, o conjunto de balizas morais de uma sociedade, refletindo anseios, valores cristalizados de modo expressivo e coletivo.

\footnotetext{
${ }^{13}$ RADBRUCH, Gustav. Filosofia do direito. 6. ed. Coimbra: Editora Arménio Amado - Editor, Sucessor, 1997.

${ }^{14}$ BITTAR, Eduardo C. B.; ALMEIDA, Guilherme Assis de. Curso de filosofia do direito. 2. ed. São Paulo: Editora Atlas, 2002.
} 
O professor Tércio Sampaio Ferraz Jr., ${ }^{15}$ por sua vez, defende em seu livro uma distinção já exposta: a que as normas jurídicas dizem respeito à conduta externa do individuo, sendo diferente dos preceitos morais que se referem ao aspecto interno do comportamento. Entretanto, diz o jurista que não se pode negar que motivos e intenções são relevantes para o Direito, além disso, preceitos morais, não são indiferentes à exterioridade da conduta, inclusive quando a intenção é tida como boa; o filósofo Gustav Radbruch, como visto, segue essa linha de pensamento.

Outro critério de distinção entre o Direito e a Moral apontado por Tércio Sampaio Ferraz Jr. seria aquele apontado na instância que qualifica o comportamento, ou seja, dizem que a moralidade dos atos repousa na própria subjetividade de quem age, já o Direito exige instâncias objetivas. Assim, a imoralidade do ato exige arrependimento do agente, isto é, o tribunal da moral seria a própria consciência; temos, nesse caso, freqüentemente a reprovação social até a agressão física, enquanto no Direito, a pressão para o cumprimento da ação licita é objetiva e depende de instâncias externas ao agente.

Em uma terceira distinção do Direito da moral demonstrada por Tércio Sampaio Ferraz Jr., temos que o fato das normas jurídicas existirem por meio de uma promulgação, em contrapartida, as normas morais desconhecem tal exigência. Cabe ressaltar que as normas costumeiras, de seu lado, seriam normas jurídicas para as quais não há também deliberação e promulgação.

O egrégio jurista, Miguel Reale, ${ }^{16}$ citou a teoria do mínimo ético para diferenciar o Direito da Moral difundida em séculos passados. Explica que o Direito representa apenas o mínimo de Moral declarado obrigatório para que a sociedade possa sobreviver. Como nem todos podem ou querem realizar de maneira espontânea as obrigações morais, é indispensável armar de força certos preceitos éticos, para que a sociedade não-naufrague. Dessa forma, o Direito seria uma parte da Moral, armada de garantias específicas e define que tudo o que é jurídico é moral, mas nem tudo que é moral é jurídico.

Entretanto, Miguel Reale observa que fora da Moral, temos o imoral, bem como o amoral, ou indiferente à Moral. Dessa forma, temos atos juridicamente lícitos que não o são do ponto de vista moral e muitas relações amorais ou imorais, segundo o jurista, realizam-se à sombra da lei. O Direito busca tutelar somente o lícito moral, mas há inevitavelmente resíduos de imoral tutelados pelo Direito.

A Moral, para Reale, como regra social, mundo de conduta espontânea do comportamento que se encontra em si própria a sua razão de existir, tem no ato moral a adesão do espírito ao conteúdo da regra. O Direito, de seu lado, é entendido como

\footnotetext{
${ }_{15}$ FERRAZ JR., Tércio Sampaio. Introdução ao estudo do direito. 4. ed. São Paulo: Editora Atlas, 2003.

${ }^{16}$ REALE, Miguel. Lições preliminares de direito. 27. ed. São Paulo: Editora Saraiva, 2002.
} 
coercível, isto é, expressão técnica para mostrar a plena compatibilidade que existe entre o Direito e a força. Temos assim, a norma somada à coação, portanto, ordem coercitiva da conduta humana.

Outra classificação do ínclito jurista é da Moral como autônoma, portanto, os preceitos autônomos se bastam por si mesmos, pelo fato de conterem em si próprios a sua finalidade, por exemplo, "Não mates". O Direito é classificado como heterônomo, ou seja, a lei pode ser injusta e iníqüa, mas enquanto não for revogada, ou não cair em manifesto desuso, obriga e se impõe contra a nossa vontade. Ele é técnico, instrumental.

Última diferença delimitada por Miguel Reale entre Direito e Moral é que o primeiro se distingue do segundo por ter o elemento bilateralidade atributiva, isto é, quando duas ou mais pessoas se relacionam, segundo uma proporção objetiva que as autoriza a pretender ou a fazer garantidamente algo. Nesse sentido, quando temos uma obrigação de compra-e-venda, os envolvidos têm um prestação um para com o outro, porém quando se tem um pedido de esmola, o pedinte pode ou não recebê-la e o doador não é obrigado a dar ou-não, pois aqui há somente um sentimento de solidariedade humana.

Miguel Reale define como sendo necessário para a existência bilateralidade no Direito a relação de duas ou mais pessoas; que esta relação seja objetiva, portanto, insuscetível de ser reduzida a qualquer dos sujeitos da relação; e a proporção estabelecida deve resultar a atribuição garantida de uma prestação ou ação, que podem se limitar aos sujeitos da relação ou estender-se a terceiros.

Nos ensinamentos do ínclito jurista H. L. A. Hart, ${ }^{17}$ a moral evolui, modificase e o Direito Positivo, diferentemente do Direito Natural, acolhe o que lhe é útil, isto é, cumpre a cada sistema jurídico selecionar o que irá para ordenamento jurídico e virará norma, pois decisões vincadas puramente na moral trazem incertezas jurídicas.

O filósofo britânico declara que o Direito é influenciado quer pela moral convencional, quer por idéias de grupos sociais particulares, quer ainda por formas de crítica moral esclarecida sustentadas por indivíduos cujo horizonte moral transcendeu a moral correntemente aceite.

Em uma sustentação mais racionalista da moral para Hart, temos os truísmos que através de seu conteúdo, permite-se ao Direito e à moral apoiar o desenvolvimento do propósito mínimo da sobrevivência comuns a ambos os conceitos. Eles dão as razões pelas quais as regras devem ter determinado conteúdo, caso contrário, os homens não as obedeceriam.

Os truísmos são enumerados da seguinte forma: vulnerabilidade humana, pois os homens são vulneráveis a ataques físicos dos outros, razão pela qual se deve

\footnotetext{
${ }_{17}$ HART, H. L. A. $O$ conceito de direito. 4. ed. Lisboa: Fundação Calouste Gulbenkian, 2005.
} 
restringir o uso da violência para matar ou causar ofensas corporais; igualdade aproximada, em que nenhum indivíduo é muito mais forte que o outro a ponto de conseguir subjugá-lo por um período prolongado sem qualquer cooperação, tornando necessário um sistema de abstenções mútuas e de compromisso com os outros, que está presente no Direito e na moral; altruísmo limitado, o altruísmo humano é limitado e intermitente, enquanto as tendências para a agressão são suficientemente freqüentes para colocar em risco a vida social, se não forem controladas; recursos limitados, a disponibilidade de recursos necessários à sobrevivência humana é limitada, exigindo uma forma mínima de instituição da propriedade, divisão do trabalho a fim de se obter recursos e um processo para se assegurarem as obrigações; compreensão e força de vontade limitadas, exigência de sanções como uma garantia de que os homens que obedecerem voluntariamente às regras não serão sacrificados aos que não obedecerem.

De uma abordagem menos racionalista da moral por Hart, temos o modo de que o Direito deve se conformar junto à moral, além do disposto pelo conteúdo mínimo de sobrevivência, do Direito Natural.

Assim, temos as seguintes enumerações: o poder e a autoridade, afirma-se que um sistema jurídico deve se basear num sentido de obrigação moral ou na convicção do valor moral do sistema, mas ser juridicamente obrigatório não seria sinônimo de moralmente obrigatório; a influencia da moral sobre o Direito, o Direito reflete não só a moral social aceite, mas também ideais morais mais amplos, pois a estabilidade dos sistemas jurídicos depende em parte de tais tipos de correspondência; a interpretação, embora a aplicação das leis aos casos concretos exija a interpretação destas pelos juízes, no sentido de não-criar injustiças ou ofender a moral vigente, isso envolve a escolha entre valores morais e não a simples aplicação de um único principio moral; a crítica do Direito, nessa crítica, pode haver desacordo não-só quanto aos padrões morais adequados, como também aos pontos de conformidade exigidos; princípios de legalidade e justiça, afirmar que um bom sistema jurídico distingue-se de um mau, em virtude da conformidade com a moral e justiça, é uma falácia, porque a justiça, na sua forma mais simples, consiste na aplicação indistinta de uma mesma regra geral a todas as pessoas, seja a regra justa ou-não. E para legalidade, para que os métodos de controle social funcionem, é necessário a inteligibilidade das regras, possibilidade de obediência pela maioria das pessoas; e por fim, validade jurídica e resistência ao Direito, regras moralmente iníqüas podem ser juridicamente válidas. Mas ser uma regra juridicamente válida não-implica automaticamente no dever de obedecê-la, deve-se sempre se fazer o juízo moral.

Portanto, para H. L. A. Hart, que adota uma visão positivista do mundo, a Moral e o Direito não se misturam, podem ter pontos em comum, mas são distintos. E não se pode isolar os conceitos a fim de que sejam objeto de estudo, devem ser observados conjuntamente. 
Eduardo Bittar e Guilherme Almeida, concluem que a moral, pelo fato de ser espontânea, informal e não-coercitiva, difere-se da ordem jurídica. Porém, ambas não se distanciam, e, sim, se complementam na orientação do comportamento humano.

Tércio Sampaio Ferraz Jr., de seu lado, afirma que o Direito Privado da moralidade perde o sentido, embora não perca necessariamente império, validade, eficácia.

Gustav Radbruch afirma que, os domínios do jurídico, direitos e obrigações, são menos exigente e requerem apenas a conduta conforme aos preceitos firmados, porém, nos domínios da moral, o dever da moral não é um débito, não é um débito para com um credor, mas simplesmente um dever, entretanto ela se manifesta pelo sentimento de cumprimento de deveres, há o espírito da moralidade e no outro, uma legalidade a ser cumprida, uma observância exterior.

\subsection{O Direito e a Moral e sua atuação prática}

Na prática, é visível que a Moral tem influência no Direito. Pode-se comprovar por meio de exemplos que os professores Eduardo C. B. Bittar e Guilherme Assis de Almeida apresentam, quais sejam:

Um primeiro exemplo está na obrigação natural como a dívida de jogo nos termo do art. 970, do Código Civil brasileiro. Trata-se de uma obrigação puramente moral, não exigível juridicamente, mas se solvida, não pode ser motivo de ação judicial, seria um pedido impossível.

A Administração Pública, por sua vez, define, em seu art. 37, caput da Constituição Federal brasileira, de 1988, além dos princípios da legalidade, eficiência, impessoalidade, publicidade, o da moralidade. Tratando a moralidade como um dever para manutenção da credibilidade dos serviços públicos.

Ainda, outro exemplo explicitado pelos juristas foi o da necessidade nos negócios jurídicos e nos tratos comerciais de existência do princípio da boa-fé.

Por fim, temos que o juiz está autorizado, juridicamente formalmente, em caso de lacuna da lei, a aplicar os costumes como forma de solução de litígio de acordo com a Lei de Introdução ao Código Civil em seu art. $4^{\circ}$.

Na Constituição Federal brasileira, de 1988, temos em seu preâmbulo os seguintes dizeres:

Nós, representantes do povo brasileiro, reunidos em Assembléia Nacional Constituinte para instituir um Estado Democrático, destinado a assegurar o exercício dos direitos sociais e individuais, a liberdade, a segurança, o bem-estar, o desenvolvimento, a igualdade e a justiça como valores supremos de uma sociedade fraterna, pluralista e sem preconceitos, fundada na harmonia social e comprometida, 
na ordem interna e internacional, com a solução pacífica das controvérsias, promulgamos, sob a proteção de Deus, a seguinte CONSTITUIÇÃODAREPÚBLICAFEDERATIVA DO BRASIL.

Declara o professor Alexandre de Morais $^{18}$ que um preâmbulo de uma Constituição pode ser definido como documento de intenções do diploma, e consiste em uma certidão de origem e legitimidade do novo texto e uma proclamação de princípios, demonstrando a ruptura com o ordenamento constitucional anterior e o surgimento jurídico de um novo Estado.

Assim sendo, quando os legisladores da Carta Suprema brasileira aceitam estar sob a proteção de Deus, é o mesmo que se declarar regidos por um ente divino, independente da religião, mas inegavelmente influenciados por uma moral que, por sua vez, há religiosamente uma necessidade de proteção celestial. Portanto, é perceptível que o íntimo da Moral está ligado ao Direito, inclusive possui a concepção religiosa geral, a da existência de um Ente Superior, isso será, pois motivo de explanação no próximo subitem desta pesquisa.

\subsection{O Direito, a Moral e a Religião}

Pensando-se que a religião é capaz de influenciar a moral de conduta de um povo, podemos inferir que ela tem a capacidade de influenciar o Direito como ocorre no Direito muçulmano, que possui como pilar de sua construção o Alcorão, Livro Sagrado do mundo islâmico.

Vejamos, segundo Antonio Augusto Machado de Campos Neto, ${ }^{19}$ citando John Gilissen, a Châr'ia muçulmana seria o "Direito" da comunidade religiosa islâmica, ou seja, o Direito que rege todos os adeptos da religião islâmica, onde quer que ele se encontrem. O Direito muçulmano seria a espécie de nómos específica de uma comunidade religiosa e não de um país.

A política da Châr'ia define os soberanos e a administração (califado), o Exército, os tributos, da mediação dos conflitos por ação dos qhâdis e os defensores das partes e das sanções.

No Direito muçulmano, temos as sanções, porém elas são advindas da tradição e relativas a aproximadamente dez delitos tomados como graves. Muitos deles o parâmetro é o flagrante, e a aplicação da pena ou castigo é facultada ao próprio lesado.

\footnotetext{
18 MORES, Alexandre de. Direito Constitucional. 19. ed. São Paulo: Editora Atlas, 2006.

19 Id. Ibid.
} 
Nos delitos contra o corpo e a vida, aplica-se o nomós de Talião, quando o delito é doloso, ou a composição, quando o delito é não-doloso poder haver a renúncia da aplicação da pena de Talião.

Quanto aos delitos de penas fixas - o mais grave é apostasia -, o ato pelo qual o muçulmano abjura de sua fé. Blasfema, ou profere palavras com injúria a Allah, a um Anjo ou Profeta. O criminoso que não se retratar desse delito, no prazo de três dias, é condenado à morte.

Outro delito é a fornicação, que é ato de relação sexual não-legitimada pela situação legal do casamento, ou de posse de uma escrava. A pena é imputada em até 100 açoites. Temos também o delito de calúnia que pode ser sancionado em até 80 açoites. Ainda há, por exemplo, o delito do furto que acarreta a amputação da mão direita do autor.

Já para os delitos não-regulados por nómos prévio, os de transgressão à preceitos divinos, as penas são de livre fixação e imputação de um mediador interventivo.

No âmbito familiar, o Direito muçulmano permite a poligamia, ou seja, o homem poderá ter quatro mulheres, com determinados nómos e honras, além das concubinas se ele não se comprometeu a se manter monógamo, bígamo ou trígamo.

Há também a proibição do casamento entre muçulmanos e não-muçulmanos, porém tal regra cessa para as mulheres muçulmanas, após a morte do marido ou posterior a um divórcio.

Admite-se somente o regime de separação de bens e o matrimonio deve seguir rigorosamente formalidades impostas na Châr 'ia muçulmana; caso contrário, será nulo.

Em relação aos juros, o Direito muçulmano é contra, bem como qualquer cláusula que vise fraudar a interdição da usura, do jogo e da especulação.

Afirma, Antonio Augusto Machado de Campos Neto, que o dispositivo relativo às sucessões se apresenta como o mais complexo. Compreende em três categorias de herdeiros e em cada uma delas existe uma subdivisão em ordem de classes. O varão, segundo o exemplo fornecido, tem um quinhão igual ao de duas mulheres. Não existe nómos de representação. Não há a admissão de sucessão contratual.

O testador jamais pode modificar a ordem de sucessão, nem favorecer determinado herdeiro, deve-se seguir primeiramente em favor dos parentes, do cônjuge sobrevivente, do senhor em relação ao liberto e, na ausência de herdeiros, ao Tesouro Público.

Relativo à propriedade, o usufruto se apresenta com duas expectativas proprietárias, a saber: um proprietário da coisa mesma e outro proprietário das vantagens que ela proporciona. 
O penhor se aplica aos imóveis, uma vez que não há hipoteca. Também não encontramos no Direito muçulmano privilégio ao vendedor que é substituído pela cláusula de retrovenda, conforme explicita Antonio Augusto.

Cabe salientar quanto ao caso das sanções supramencionadas, em que, no Direito ocidental, defende-se o caráter não-cruel delas, principalmente àqueles protetores dos Direitos Humanos, porém não se deve aqui distinguir se tais penas do Direito muçulmano são boas ou más, mas, sim, aceitá-las; afinal, não se trata de um povo qualquer, trata-se de uma outra civilização com seus próprios costumes e condutas, logo respeitá-los é o mínimo a se fazer.

Analisando a Châr'ia Muçulmana, é possível se inferir que, ao mesmo tempo, temos uma Religião formadora de uma Moral do povo islâmico, e uma Religião capaz de definir o Direito a ser aplicado para conduzir as relações interpessoais, familiares e comerciais desse grupo social muçulmano.

É de fácil visualização da importância da Religião ao povo islâmico através da seguinte reportagem, datada do dia 27 de julho de 2005 do jornal de grande circulação Folha de S.Paulo, em que se declarava o seguinte:

$\mathrm{O}$ islã será a principal fonte de legislação do Iraque e a religião oficial do Estado, segundo uma versão preliminar da nova Constituição divulgada ontem. A determinação põe abaixo as expectativas dos EUA de que o Estado iraquiano se mantivesse totalmente laico e alimenta temores entre grupos de direitos civis - sobretudo os femininos.

"Nenhuma lei que contradiga as regras [do Islã] poderá ser promulgada", diz o texto publicado no jornal oficial "Al Sabah". A versão final da Carta deve ser apresentada até 15 de agosto para ratificação na Assembléia Nacional e ir a plebiscito no fim do ano.

Assim sendo, é perceptível que o Direito, nos países islâmicos, é formado com base nas condutas Moral-Religiosa, logo os três conceitos se unem como um só demonstrando tamanha importância que o mundo muçulmano tem quanto aos dogmas religiosos em suas vidas.

Dessa forma, não cabe ao mundo ocidental julgar se tais condutas jurídicoreligiosas são certas ou erradas, pois toda estrutura islâmica está baseada em costumes morais-religiosos de séculos passados cultivados e protegidos até os dias atuais.

\section{Conclusão}

A concepção da moral varia conforme o tempo e o lugar. Temos que tal conceito é fator determinante para definirmos o modo de conduta dos povos, suas crenças e relações interpessoais. No mundo medieval, por exemplo, não havia a valorização 
do trabalho e, sim, do ócio, dos títulos de senhores de terra, porém com o advento e desenvolvimento da burguesia, passa-se a buscar o acúmulo de bens por meio do labor, fato moralmente condenado anteriormente.

Entretanto, a moral não existe por si só, ela possui fundamentos, princípios, crenças a serem seguidas. Sua força está nas sanções psicológicas, assim, o que move ou impede os atos humanos, estariam regulados interiormente, no âmago. Dessa forma, é passível de conexão com a capacidade que a religião tem em influenciar as condutas morais de um determinado povo, país. É o exemplo de nações do Oriente que adotam o Alcorão como principal norte para qualquer ato da vida humana, seja comercial, seja familiar.

Nesse contexto que citamos o Direito, um conjunto de regras cogentes que garantem a convivência social de maneira pacífica por meio de leis limitantes, de certa forma, da liberdade dos indivíduos. É inegável que, antes do estudo detalhado do Direito, comprova-se o prevalecimento das leis divinas, leis naturais, que respondiam por si mesmas, não se permitiam ser questionadas, mas na medida que a complexidade das relações dos homens aumentava, os sistemas de ordenamento social passavam a exigir mais dos filósofos, estudiosos até que a ciência jurídica se tornou imprescindível para a sociedade.

Ora, é possível se inferir que o Direito, a Moral e a Religião andam em consonância, a diferença de um ordenamento social para outro está na dosagem de Moral ou de Religião sobre o Direito. Embora se pense que tal influência é incomum nos dias atuais, enganamo-nos, pois é usual encontrar um Direito que absorveu dogmas religiosos ou morais em sua estrutura interna, foi o caso do Direito muçulmano, tema aberto nesta pesquisa.

Além disso, muitos países hodiernamente declaram-se laicos, como é o caso do Brasil, porém no Preâmbulo da Constituição-Cidadã, de 1988, há o trecho "sob a proteção de Deus" corroborando a existência, no momento de sua elaboração, de uma moral-religiosa.

Pois bem. Direito e Moral não são confundidos, andam em harmonia, tocamse. O segundo, inevitavelmente influencia o primeiro, suas diferenças foram demonstradas por meio das grandes teorias de eméritos juristas e filósofos. A Religião, por sua vez, pode da mesma forma que prepondera sobre a moral de um povo, exercer grande influência sobre o Direito, ditando condutas essenciais para estruturação de um ordenamento jurídico válido em determinado território.

São Paulo, maio de 2008. 


\section{Referências}

ARANHA, Maria Lucia de Arruda; MARTINS, Maria Helena Pires Martins. Filosofando: introdução à filosofia. 2. ed. São Paulo: Editora Moderna, 1993.

ALVES, Alaôr Caffé; LAFER, Celso; GRAU, Eros Roberto; COMPARATO, Fábio Konder et al. $O$ que é filosofia do direito. São Paulo: Editora Manole, 2004.

BITTAR, Eduardo C. B.; e ALMEIDA, Guilherme Assis de. Curso de filosofia do direito. 2. ed. São Paulo: Editora Atlas, 2002.

BOBBIO, Norberto. A era dos direitos. 3. tir. Rio de Janeiro: Editora Campus, 2004.

BOBBIO, Norberto. O positivismo jurídico. São Paulo: Editora Ícone, 1995.

BOBBIO, Norberto. Locke e o direito natural. 2. ed. Brasília: Editora Unb, 1997.

CAMPOS NETO, Antonio Augusto Machado de. A Châr'ia Muçulmana. Revista da Faculdade de Direito da Universidade de São Paulo, São Paulo, v.101, p.33-70, 2006.

FERRAZ JR., Tércio Sampaio. Introdução ao estudo do direito. 4. ed. São Paulo: Editora Atlas, 2003.

FIORIN, José Luiz. As astúcias da enunciação. 2. ed. São Paulo: Editora Ática, 2002.

HART, H. L. A. O conceito de direito. 4. ed. Lisboa: Fundação Calouste Gulbenkian, 2005.

KELSEN, Hans. Teoria pura do direito. 6. ed., 5. tir. São Paulo: Editora Martins Fontes, 2003.

MORAES, Alexandre de. Direito constitucional. 19. ed. São Paulo: Editora Atlas, 2006.

RADBRUCH, Gustav. Filosofia do direito. 6. ed. Coimbra: Editora Arménio Amado - Editor, Sucessor, 1997.

REALE, Miguel. Filosofia do direito. 17. ed. São Paulo: Editora Saraiva, 1996.

REALE, Miguel. Lições preliminares de direito. 27. ed. São Paulo: Editora Saraiva, 2002.

VOLTAIRE. Dicionário Filosófico. São Paulo: Ed. Martin Claret, 2004.

Folha de S. Paulo, São Paulo, domingo, 12 de agosto de 2001.

Folha de S. Paulo, São Paulo, quarta-feira, 27 de julho de 2005.

Grande Enciclopédia Larousse Cultural. Editora Nova Cultura, 1998. 